\title{
Stride of Service Sector in Nepal's Trajectories of Structural Change
}

\author{
Madhav Prasad Dahal, PhD. \\ Associate Professor, Tribhuvan University, Patan Multiple Campus, Nepal
}

\begin{abstract}
Agriculture, manufacturing and service sectors are the major economic sectors of a country. The long held view is that economies' development trajectories move from agriculture to manufacturing to services. These conclusions are primarily based on the studies of developed countries. However more recent studies relating to developing countries have brought evidences that the structural transformation path is not linear as experienced by today's developed countries. Nepal is not an exception is experiencing the waves of sector-wise structural transformation. Using time series data of the period 1975-2016 of the economy of Nepal this paper analyses the association between gross value added and service sector value added in the analytic-framework of the autoregressive distributed lag (ARDL) to cointegration. The empirical result reveal a cointegrating relationship between real gross value added and service sector value added. Result also show service sector enhancing role of education and export trade of Nepal. The paper finally draws few policy implications essential for service sector sustainability to support overall economic growth.
\end{abstract}

Key words: Structural change, service-sector, economic growth,

JEL Classification: O11, O14, O40, O47

\section{INTRODUCTION}

Economies experience changes in the structure of sectoral output and employment. "Structural change essentially refers to changes in sectoral composition of output and employment contributing to higher economic growth and increased utilisation of underutilized resources, especially labour" (Tregenna,2015, p.6).In their influential works Fisher (1935) and Clark (1940) proposed that the development of an economy shifts from agriculture to manufacturing to services. In line with Fisher-Clark hypothesis the earlier theoretic contributions proposed a linear path of transformation in which resources, for instance labour and capital, move from agriculture sector to the manufacturing sector (Chenery, 1960; Chenery \& Syrquin, 1975; Chenery, Robinson \& Syrquin, 1986; Kuznets, 1966). The two sector development model devised by Lewis (1954) gives emphasis to the concept of transformation in terms of shifts in labour shares from agriculture to industry. Such transformation is sensed to be beneficial, 
considering that the manufacturing sector implants larger benefits than traditional agriculture sector. In his stages of development theory Rostow (1960) brought forward the hypothesis that an economy passes from a pre-Newtonian era to the stage of high mass consumption. The long held view on structural change in the broad sectors of an economy is thus "the basic shift in the center of gravity of the economy from primary production to manufacturing and later to service" (Chenery, 1988, p.199).

More recent studies suggest that the growth of the service sector does not happen in a linear path from agriculture to manufacturing and/then to services. For instance, Eichengreen and Gupta (2013) propose that the increasing share of services in the economy occurs in two waves: during the first wave, traditional services arise at low levels of income; and a second at higher levels of income the share of services increases more and mainly includes modern services, including communication, finance, computer and business services. Considering the pattern of deindustrialisation in low-and middle-income countries, Rodrik (2016) reasons that developing countries arrive their manufacturing peak (measured as manufacturing real value added as a percent of GDP) at an earlier time which he calls 'premature deindustrialisation', with an increasing share of activity and employment taking place in the services sector, although at low-productivity level.

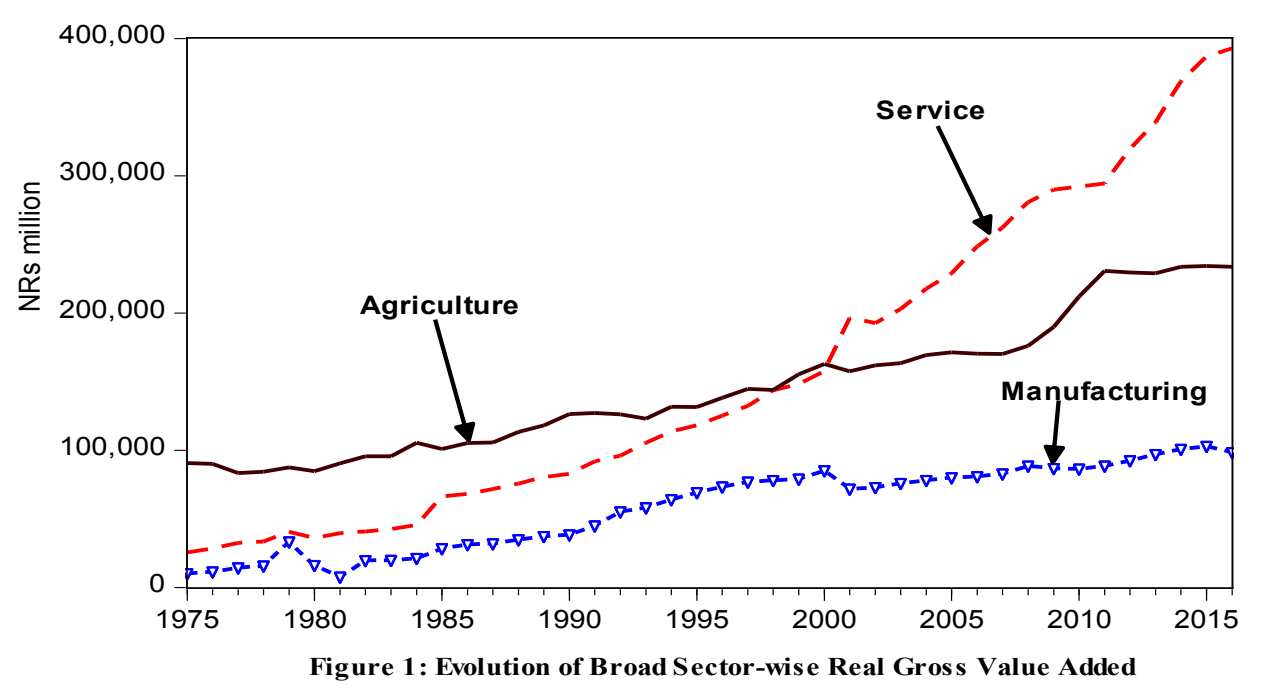

All economies whether developed or developing experience the wave of structural change in terms of change in labour employment, resource allocation and productivity 
among broad economic sectors.Structural changehas been deemed crucial to developing countries "catching up" with developed countries(Tregenna, 2015). One of the ways of analyzing the changing structure of the output of an economy is to visualise trends of the size of output by grouping them in three broad sectors: the primary (agriculture and mining) sector, the secondary (manufacturing and construction) sector, and the tertiary (services) sector. The evolution in the size of the broad sector-wise real output of the economy of Nepal over the period of 1975-2016 is revealed in Figure 1.

As is obvious from Figure 1 prior to 2000 the size of output originating from the primary sector was more than the output from both the secondary and tertiary sectors. However after the year 2000 the output originating from the tertiary (services) sector is in lead of the output of the other two broad sectors. The trend of the structural change in the production activities may also be traced by looking at the output of the primary, secondary and tertiary sectors as a share of gross value added of the economy. This is shown in Figure 2.

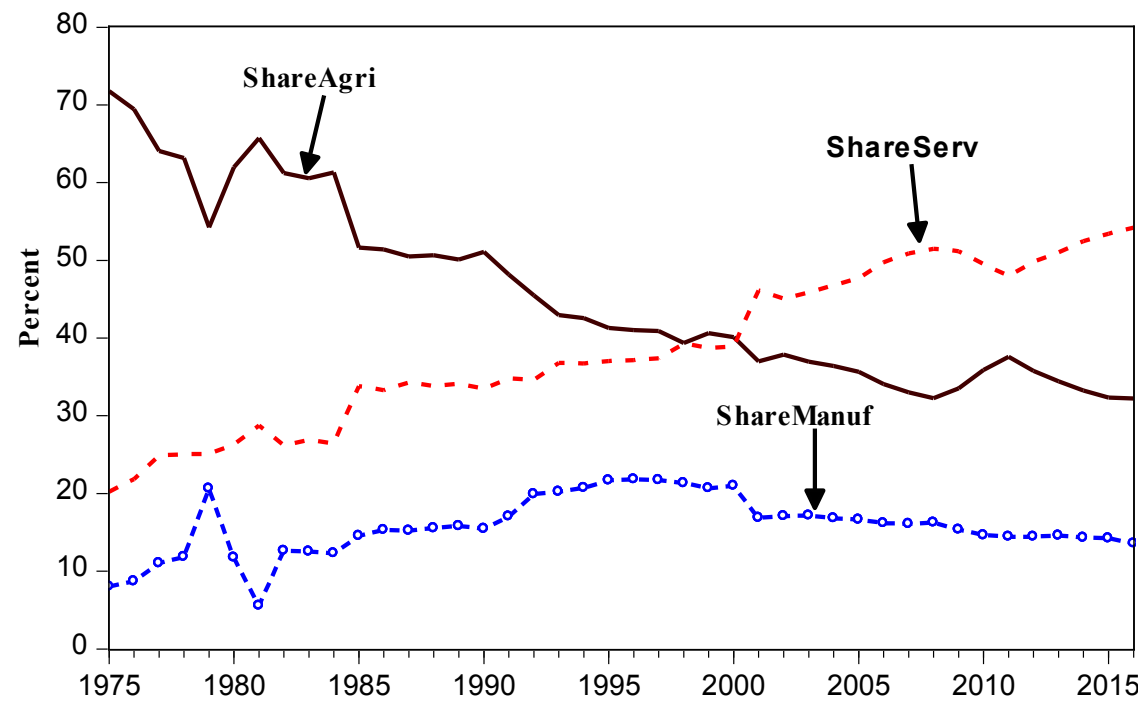

Figure 2: Output Shares of Broad Sectors, Nepal

Figure 2 reveals that the share of output originating from the agriculture sector (ShareAgri) is in continued decline while the share of output of the services sector (ShareServ) is in continued rise over the period of 1975 to 2016. But the share of output originating from the manufacturing sector (ShareManuf) of the economy is low from the start of the period and it is gradually falling after 2000. Thus there is clear-cut indication of the lead of the service sector in the broad sector-wise structural transformation in the economy of Nepal amid the declining agriculture and curiously low performance of 
the manufacturing sector. From Figure 1 and 2 it appears that immediate after the year 2000 services have surpassed agriculture and manufacturing as source of economic growth in Nepal. The low and declining share of the manufacturing sector signals that some form of pre-mature deindustrialisation have set in Nepal.

Services play a crucial role different from agriculture and manufacturing in economic transformation and job creation in low income countries (LICs) but there are fewer studies that analyse the role of service sector in the context of poor countries like Nepal. As Hoekman and te Velde (2017, p.1) observe, "While much of the discussion on economic transformation centres on transforming agriculture and moving into manufacturing, services are an underexplored component of economic transformation strategies". The study of the role of service sector in economic transformation is useful to policy-makers to update their understanding on the linkages among sectors and consider what particular actions would be worthy of priority.

On the above background this paper has two objectives: first is to analyse empirically the impact of service sector on the economic growth, and the second is to identify whether real gross domestic product (GDP) as a proxy of income would be a determinant of service sector value added in the economy of Nepal. This paper applies the method of autoregressive distributed lag (ARDL) to cointegration to analyse both the issues. To the best of this author's knowledge such an empirical analysis on the issue has not been made in the context of a least developed country like Nepal, and in the global context too there is limited empirical evidence and the approach of ARDL is hardly used to investigate the issue. Much of the studies on the process of development and structural change have been made and documented in relation to advanced economies. The contribution of this paper is to add empirical evidence on the impact of service sector on economic growth by bringing the case of Nepal (a least developed country) in the stage. It is worthwhile to analyse the possible linkage between service sector and GDP simultaneously than singly.

The rest of the paper is structured as follows: Section 2 reviews literature to draw conclusion on what has been done on the issue. A theoretical framework on the concepts of services and the role of services as a mechanism of growth is presented in section 3 . Specification of the model is given in section 4 .Section 5 contains data sources. Section 6 describes the econometric approach applied in the study. Results and discussion are given in section 7.Section 8 presents some policy implications based on the findings. Finally, section 9 offers conclusion. 


\section{REVIEW OF LITERATURE}

There is much theoretical discussion on the effect of the service sector in the economic transformation of economies but there are limited number of empirical studies investigating the impact of service sector on the economic growth of a country. Most of the available studies are cross-sectional or panel data-based. Moreover the available studies have tested whether growth in service sector depends upon the growth of national income or growth in gross domestic product. The literature reviewed here covers studies made since the second half of the 1950s and that have at least attempted to explore the association among services, income/output or employment from macroeconomic perspectives.

To begin with, Kuznets (1957) in the analysis of the levels and trends of the shares of major industrial sectors in national product and labour force of a large number of countries concluded that the share of services in national product did not vary significantly with per capita income. Kuznets acquired a significant advance in the study of the long-run growth by measuring the structural transformation as a whole rather than dealing with each part separately. This synthesis helped in the identification of the uniform patterns of growth in demand, production, trade, and employment. Although the estimates were originally made separately from time series data for developed countries and from cross-section data for less developed countries, Kuznets' main findings have proven to be pretty influential with regard to more comprehensive econometric analyses.

Chenery (1960) by regressing the share of services on per capita income on cross country data, found positive but an insignificant coefficient and concluded that there was no stable relationship between services and per capita income across countries. Using data of the period 1950-1970 Chenery and Syrquin (1975) regressed the service-sector share of output on per capita income and per capita income squared and concluded that the relationship was concave to the origin (the coefficient of the squared income term was negative) which implied that share of service sector increased with the rise in per capita income but at a decreasing rate.

Ansari (1995) using annual data of the period 1973-1991 from India, Pakistan and Sri Lanka tested the relevance of the secular trend and the Bacon-Eltis (1978) view of structural change in these economies. The secular trend view of structural change hypothesises that society attempts to reallocate available resources in response to changing tastes and income. Accordingly when income rises higher the subsistence level, the proportion of income spent on goods falls leading to growth in the tertiary (service) sector eventually. The Bacon-Eltis view understands structural change as an outcome of the rapid expansion in the public sector shifting away resources from manufacturing industrial sector in favour of services (Ansari, 1995). The results from 
both the individual country analysis and the combined cross-section and time-series analysis produced support to both the secular trend and the Bacon-Eltis views. However in the study of individual country the coefficient of the government expenditure term was negative for Sri Lanka. In analysing the association among economic growth, and share of agriculture, manufacturing and services Kongsamut, Rebelo and Xie (2001) found the share of services in output to be linear in per capita income.

Gani and Clemes (2002) studied the determinants of per capita economic growth in the group of ASEAN economies using panel data from 1965 to 1994 with particular attention paid to the contribution of services to the growth of real GDP per capita. In the GDP growth regression the study included population growth, ratio of investment to GDP, primary and secondary school enrolment ratios, inflation rate, and share of service sector in the GDP. In the regression of the service sector growth the prime regressors were growth of real output, growth of manufacturing sector, growth in real exports, growth in imports, and government expenditure on infrastructure. Estimation results of a structural per capita growth equation revealed that growth of services exerts a statistically significant positive effect on the overall economic growth in the panel of countries. In addition, the results substantiate a strong positive influence of growth in manufacturing and government spending on service sector growth. Moreover, services also showed a spillover effect on manufacturing. Ghani (2010) in a cross country growth regression found that both service and manufacturing sectors are important to GDP growth but that the service sector has a stronger correlation with overall growth than the manufacturing sector.

Eichengreen and Gupta (2013) use panel data and regress the percentage share of services in the GDP upon four powers of log of per capita income (linear, squared, cube and quartic), interaction terms, trade share, share of urban population, and age dependency ratio. Empirical results showed two tendencies: the first tendency is the growth of traditional services in countries with relatively low levels of income, and the second tendency is the increase in modern services in countries with relatively higher level of per capita income. The study also documented the occurrence of the second tendency in countries at lower income levels after 1990 that were more democratic, open to trade, and close to global financial centres.

\section{THEORETICAL FRAMEWORK}

This section introduces concept of services and highlights the role of the service sector in economic growth, employment creation, and productivity changes.

\section{Concept of Services}

The task of defining services remains tough as service sector comprises of a large variety of economic activities. In the words of Riddle and Sours (1984, p.191), “Services 
are primarily processes of potential benefits to the consumer, rather than tangible objects for which the consumer receives ownership title". World Bank (2009) mentions two categories of services: traditional personal services and modern impersonal services. Traditional personal services comprise what Baumol (1985) calls "stagnant personal services" such as trade, hotel, restaurant, beauty shops, barbers, education, and health. These services often need direct interaction, and the use of information and communication technology (ICT) in them is limited. Traditional services also consist of "stagnant impersonal services" such as transport, government, and public administration services. Stagnant personal and stagnant impersonal services benefit less from ICT and technological changes, even though there is space for improving their productivity with the use of technology, for example, increased use of ICT in retail and wholesale business and government services (World Bank, 2009). Stagnant services suffer from "cost disease" and rising prices because productivity growth in these sectors falls behind the rest of the economy (Baumol, 1967, 2001; Baumol, Blackman, \& Wolff, 1989).

Modern impersonal services include what Baumol (1985) calls "progressive impersonal services". This category includes communication, banking, insurance, and business related services. These services take advantage of ICT, globalization, scale economies, and benefit from higher productivity growth rates.

Singlemann (as cited in Riddle \& Sours, 1984) categories services into four groups: (i) distributive services which include transportation, communication and trade, (ii) producer services which include banking and real estate, infrastructure industries essential for economic growth and development, and professional consultative services rendered to businesses, (iii) social services comprising of governmental and quality of life services that provide health, education or welfare services, and (iv) personal services which include recreation, lodging, food, and repairs that were once produced within the household and have become specialized market products with the increase in urbanisation.

\section{Role of Services in Economic Transformation}

Service sector of an economy is contributory in the economic development and growth from several angles. The conclusion reached by Riddle (1986,p.26) on the role of services in an economy is that, "Services are the glue that holds the economy together, the industries that facilitate all economic transactions, and the driving force that stimulates the production of goods". Services sector contributes in the production of a nation's output and creation of employment, and also provides necessary inputs (e.g., logistic, energy, financial, or information and communication technology services) for the rest of the economy. The state of adequacy and efficiency of the service sector of an 
economy has impact on the investment climate which is a basic determining factor of economic growth and development. Some service sectors such as health, education, water and sanitation are also directly relevant to achieving social development objectives. Services contribute in the economic transformation of a country which include moving labour between sectors, improving factor productivity, diversifying foreign trade, among others.

In today's world partly because of the revolution in information and communication technology (ICT) services are increasingly used as intermediate inputs in production in the form of business services with great benefits for productivity and quality throughout the economy (Fixler \& Siegel, 1999; Greenhalg \& Gregory, 2001; Oulton, 2001).Literature documents that service sector in a developing country affects the economy's economic transformation through its three broad effects (International Finance Corporation (IFC), 2013; Jouanjean, Mendez-Parra \& te Velde, 2015; Balchin et al., 2016) :(i) direct impact (employment, exports, GDP), (ii) indirect impacts through input-output analysis (jobs and output in supplier industries), and (iii) second round effects (e.g., productivity effects and forward linkages). A general framework architectured by Khanna, Papadavi, Tyson and te Velde (2016) for revealing the contribution of the services sector to employment and output for the economy of Kenya is shown in Table 1.

Table 1 highlights that different services sector have different impact in employment generation, output creation and export earnings. For example, sectors like retail trade, accommodation and, in part, health and education, seem important in creating jobs for less to medium-skilled workers whereas finance and insurance, professional services sectors appear to be favourable for skilled workers. Service sectors like education, finance and insurance, real estate, transport and storage, wholesale and retail trade tend to be main parts of GDP while others are less important contributors to GDP directly. In the context of export earnings sectors such as information and communication technology (ICT), finance, transport, and accommodation can contribute more but sectors like public administration and health and education cannot add in most countries. Sectors for instance accommodation, retail and transport can also have important impacts on suppliers. ICT, finance, and transport sectors can have important effect on the economy-wide productivity in the medium run but real estate and accommodation sectors can have no impact, and health and education sectors show their impact only in the very long run (Balchin et al, 2016). Thus it is obvious that there is heterogeneity in the way different types of services contribute to economic transformation of a country. 


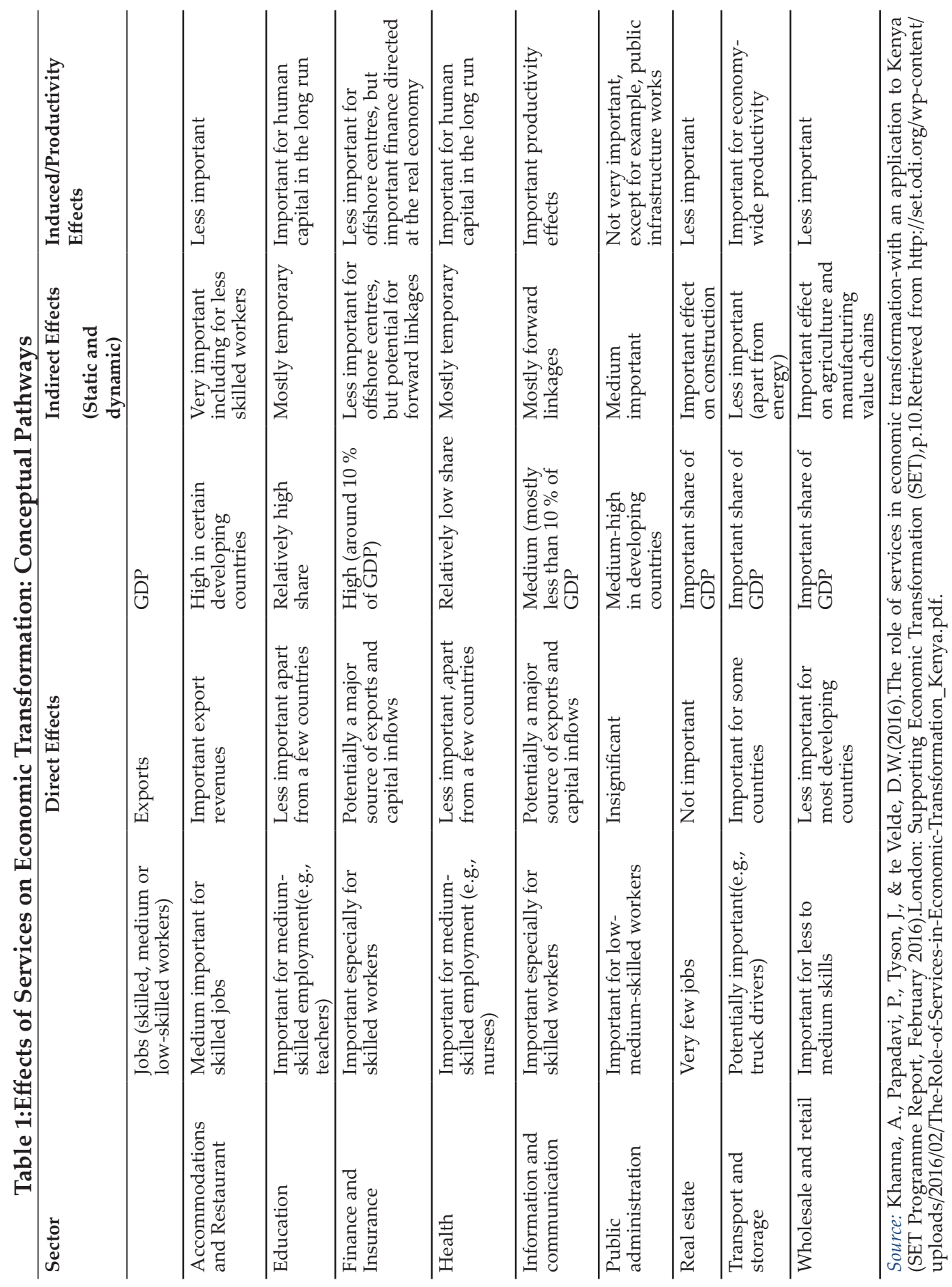




\section{SPECIFICATION OF MODEL}

The specification begins with the assumption that the level of real GDP is primarily a function of the level of factor supplies. The key variables used in the exact specification are mostly the main conventional variables used in cross-country and country specific growth regressions (for example, Altug, Filiztekin, \& Pamuk, 2008; Gani \& Clemes, 2002; Jalil \& Idrees, 2013; Mankiw, Romer, \& Weil, 1992; Rao \& Vadlamannati, 2010; Senhadji, 2000).Therefore drawing upon the literature reviewed and the theoretical framework presented under the "role of services in economic transformation", growth model (1) is used for the first objective of the study:

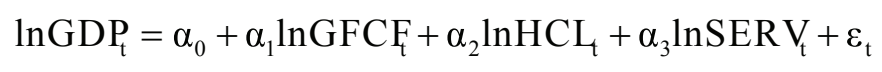

where GFCF is gross fixed capital formation, a proxy measure of capital stock, a conventional input entered in economic growth model; HCL is education-centric human capital adjusted measure of labour force; SERV is service sector gross output; $\ln$ is shorthand of natural logarithm, $\varepsilon$ is the stochastic error term, and $t$ is an index of time. The natural logarithm transformation of the variable allows to capture the elasticities of the variables by their associated coefficients.

Drawing upon Chari, Kehoe and McGrattan (1997), Hall and Jones (1999), and Senhadji (2000) this paper has picked the level of the variables rather than their first differences or growth rates. Chari et al analyse levels of economic performance among countries. Particularly in economic growth literature Hall and Jones (1999), and Senhadji (2000) argue in favour of level relation among macroeconomic variables. Senhadji brings the cointegration literature in the context to state that much more is known about the long-run than the short-run relationship between macroeconomic variables. The cointegration literature has demonstrated the superiority of level equation as opposed to first-difference when series are nonstationary; the first difference operator removes all the long-run information in the data. Senhadji further reasons that the business cycle frequencies of the production process may be dominated by differences in capacity utilization factors that are difficult to measure especially for developing countries. The growth study of Easterly, Kremer, Pritchett and Summers (1993) shows that growth rates over decades are only weakly correlated, suggesting that country differences in growth rates may in essence be transitory.

Since the time series of capital stock of the economy of Nepal is not available, this study employs gross capital formation as a proxy of capital stock. Due to the unavailability of time series on employment the size of the labour force is proxied by the estimated number of economically active population which is then scaled by the variable 'school enrollment' as a fraction of estimated number of total population. Thus the variable 
HCL is a blending of Solow (1956) type of neoclassical growth model and the LucasRomer (Lucas, 1988; Romer, 1990) class of new/endogenous growth theories. Service sector output is entered as a structural variable. Service sector affects the level of GDP directly being a part of total value added and indirectly via influencing efficiency and productivity of economic activities.

This study also aims to know whether services have a nature to depend on the level of income as claimed by the 'hierarchy of needs hypothesis'. Therefore for the second objective of this study service sector value added is hypothesised to depend upon the domestic income level proxied by the level of real GDP. For this the service output is regressed on the log of real GDP along with other control variables as specified in the core model (2):

$$
\ln \mathrm{SERV}_{\mathrm{t}}=\beta_{0}+\beta_{1} \ln \mathrm{GDP}_{\mathrm{t}}+\beta_{2} \ln \mathrm{X}_{\mathrm{t}}+\beta_{3} \ln \mathrm{M}_{\mathrm{t}}+\beta_{4} \ln \mathrm{G}_{\mathrm{t}}+\beta_{7} \ln \mathrm{HCL}_{\mathrm{t}}+v_{\mathrm{t}}
$$

where $\ln X$ is the natural $\log$ of the level of real exports, $\ln M$ is the natural $\log$ of the level of real imports, $\operatorname{lnG}$ is the natural $\log$ of government's capital expenditure in real terms, and $v$ is the stochastic error term. The government expenditure variable is included following Bacon-Eltis's (1978) interpretation of the structural change. The Bacon-Eltis view perceives structural change as the outcome of rapid expansion of the public sector.

The export $(\ln X)$ variable is included because the link of the domestic economy to the international economy may have a positive effect on service sector growth inasmuch as it introduces greater degree of competition, keeps the economy linked with the newest technological developments and leads to higher levels of investment. Consequently it can enhance efficiency and productivity of the domestic services sector. The import variable $(\operatorname{lnM})$ is also captured in the specification because it is an important means of supplying crucial inputs as well as rising the level of technology, and it is anticipated to have a positive effect on productivity growth in the service sector.

\section{DATA}

The data used in this study are compiled from different secondary sources. The data on GDP, and sectoral output are taken from the national account data prepared by the Central Bureau of Statistics (CBS), Government of Nepal and Economic Surveys of several years published by Ministry of Finance, Government of Nepal. The data on the export and import trade of Nepal are extracted from the Quarterly Economic Bulletins published by Nepal Rastra Bank, the Central Bank of Nepal. The data on gross fixed capital formation (GFCF) are taken from Economic Surveys of several years 
published by Ministry Finance, Government of Nepal. The data on government capital expenditure, GDP deflator, and school level total enrollment (from grade 1 to 10) are also compiled from Economic Survey of fiscal years 2010/11(Volume II), 2012/13 and 2016/17 published by Ministry of Finance, Government of Nepal. Current price data of GDP, broad sector-wise output (value added), export, import, GFCF, and government capital expenditure are transformed into real term by deflating them by the implicit GDP deflator of base year 2001.

The time series data on total population and economically active population of Nepal are not available. So they are interpolated and extrapolated by using the constant growth rates of the inter-census data of the years 1971,1981,1991,2001 and 2011.The sample period of analysis is 1975-2016.

\section{ECONOMETRIC METHOD}

To analyse whether a cointegrating relation exists in the models specified in equations (1) and (2), this paper uses the autoregressive distributed lag (ARDL) approach to cointegration propounded by Pesaran and Shin (1999) and Pesaran, Shin and Smith (2001). Conventional methods of estimating cointegrating relationships, such as EngleGranger (1987) or Johansen's $(1991,1995)$ method, or single equation methods such as Fully-Modified ordinary least squares method (FM-OLS) of Phillips and Hansen (1990),or Dynamic ordinary least squares (DOLS) method of Stock and Watson (1993), require all variables to be I(1).The ARDL approach to cointegration has the advantage that the variables in the cointegrating relationships can be either $\mathrm{I}(0)$ or I(1) or a mix of both. In addition Pesaran and Shin remark that unlike other methods of estimating cointegrating relationships, the ARDL representation does not require symmetry of lag lengths; each variable can have a different number of lag terms.

An autoregressive distributed lag (ARDL) is a least squares regression consisting of lags of the dependent and explanatory variables as regressors (Greene, 2008). ARDLs are usually denoted with the notation $\operatorname{ARDL}\left(\mathrm{p}, \mathrm{q}_{1}, \ldots . . \mathrm{q}_{\mathrm{k}}\right)$, where $\mathrm{p}$ is the number of lags of the dependent variable, $q_{1}$ is the number of lags of the first explanatory variable, and $q_{k}$ is the number of lags of the kth explanatory variable. Following Pesaran and Pesaran (2009) and Pesaran, Shin and Smith (2001) an augmentedARDL( $\left.\mathrm{p}, \mathrm{q}_{1}, \mathrm{q}_{2} \ldots . . \mathrm{q}_{\mathrm{k}}\right)$ model can be inscribed as follows:

$$
\begin{aligned}
& \alpha(L, p) Y_{t}=\sum_{i=1}^{k} \gamma_{i}\left(L, q_{i}\right) X_{i t}+\lambda^{\prime} W_{t}+\varepsilon_{t} \\
& \text { Where, } \alpha(L, p)=1-\alpha_{1} L-\alpha_{2} L^{2}-\ldots-\alpha_{p} L^{p}, \\
& \gamma_{i}\left(L, q_{i}\right)=\gamma_{i 0}+\gamma_{i 1} L+\gamma_{i 2} L^{2}+\ldots+\gamma_{i q_{i}} L^{q_{i}}, i=1,2, \ldots, k
\end{aligned}
$$


$\mathrm{Y}_{\mathrm{t}}$ is the dependent variable, $\mathrm{X}_{\mathrm{it}}$ is the $\mathrm{i}$ explanatory variable, $\mathrm{L}$ is a lag operator such that $L Y_{t}=Y_{t-1}, W_{t}$ is a $S x 1$ vector of deterministic variables including intercept term, seasonal dummies, time trends or exogenous variables with fixed lags, and $\varepsilon$ is stochastic error term.

Some of the explanatory variables, $X_{i}$, may have no lagged terms in the model $\left(q_{i}=0\right)$. These variables are called static or fixed regressors. Explanatory variables with at least one lagged term are called dynamic regressors. In the ARDL method the optimum lags are selected following the famous Akaike Information Criteria (AIC) or the Schwarz Bayesian Criteria (SBC) or the Hannan-Quinn Criteria (HQC). Then the long-run coefficients and their asymptotic standard error are calculated for the selected ARDL model. Following Pesaran and Pesaran (2009) the long-run coefficients for a response of $Y_{t}$ to a unit change in $X_{i t}$ are estimated by

$$
\omega_{i}=\frac{\widehat{\gamma}_{i}\left(1, \widehat{q}_{i}\right)}{\widehat{\alpha}(1, \widehat{p})}=\frac{\widehat{\gamma}_{i 0}+\widehat{\gamma}_{i 1}+\ldots+\widehat{\gamma}_{i \widehat{q}_{i}}}{1-\widehat{\alpha}_{1}-\widehat{\alpha}_{2}-\ldots-\widehat{\alpha}_{\widehat{p}}}, i=1,2, \ldots, k
$$

where $\widehat{\mathrm{p}}$ and $\widehat{\mathrm{q}}_{\mathrm{i}}, \mathrm{i}=1,2, \ldots, \mathrm{k}$ are the selected (estimated) values of $\mathrm{p}$ and $\mathrm{q}_{\mathrm{i}}, \mathrm{i}=1,2, \ldots, \mathrm{k}$.

According to Pesaran and Pesaran (2009) the long-run coefficients related to the deterministic/exogenous variables with fixed lags are estimated by:

$$
\widehat{\pi}=\frac{\hat{\lambda}\left(\widehat{\mathrm{p}}, \widehat{\mathrm{q}}_{1}, \widehat{\mathrm{q}}_{2}, \ldots, \widehat{\mathrm{q}}_{\mathrm{k}}\right)}{1-\widehat{\alpha}_{1}-\widehat{\alpha}_{2}-\ldots-\widehat{\alpha}_{\hat{\mathrm{p}}}}
$$

Where $\hat{\lambda}\left(\widehat{\mathrm{p}}, \widehat{\mathrm{q}}_{1}, \widehat{\mathrm{q}}_{2}, \ldots, \widehat{\mathrm{q}}_{\mathrm{k}}\right)$ denotes the OLS estimates of $\lambda$ in equation (3) for the selected ARDL model.

The error correction model (ECM) related to the ARDL $\left(\widehat{\mathrm{p}}, \widehat{\mathrm{q}}_{1}, \widehat{\mathrm{q}}_{2}, \ldots, \widehat{\mathrm{q}}_{\mathrm{k}}\right)$ model can be obtained by writing equation (3) in terms of the lagged levels and the first differences of $\mathrm{Y}_{\mathrm{t}}, \mathrm{X}_{1 \mathrm{t}}, \mathrm{X}_{2 \mathrm{t}}, \ldots, \mathrm{X}_{\mathrm{k}}$ and $\mathrm{W}_{\mathrm{t}}$ (Pesaran \& Pesaran, 2009).Thus,

$$
\Delta \mathrm{Y}_{\mathrm{t}}=-\alpha(1, \mathrm{p}) \mathrm{ECT}_{\mathrm{t}-1}+\sum_{\mathrm{i}=1}^{\mathrm{k}} \gamma_{\mathrm{i} 0} \Delta \mathrm{X}_{\mathrm{it}}+\lambda^{\prime} \Delta \mathrm{W}_{\mathrm{t}}-\sum_{\mathrm{j}=1}^{\hat{\mathrm{p}}-1} \alpha_{\mathrm{j}}^{*} \Delta \mathrm{Y}_{\mathrm{t}-\mathrm{j}}-\sum_{\mathrm{i}=1}^{\mathrm{k}} \sum_{\mathrm{j}=1}^{\hat{\mathrm{q}}_{\mathrm{i}}-1} \gamma_{\mathrm{ij}}^{*} \Delta \mathrm{X}_{\mathrm{i}, \mathrm{t}-\mathrm{j}}+\mathrm{v}_{\mathrm{t}}
$$

where $\mathrm{ECT}_{\mathrm{t}}$ is the error correction term defined by: $\mathrm{ECT}_{\mathrm{t}}=\mathrm{Y}_{\mathrm{t}}-\sum_{\mathrm{i}=1}^{\mathrm{k}} \hat{\omega}_{\mathrm{i}} \mathrm{X}_{\mathrm{it}}-\bar{\pi}^{\prime} \mathrm{W}_{\mathrm{t}}$

It is relevant to remember that $\alpha(1, \hat{p})=1-\widehat{\alpha}_{1}-\widehat{\alpha}_{2}-\ldots-\widehat{\alpha}_{\hat{p}}$, and it measures the numerical worth of the error correction term. The remaining coefficients $\alpha_{j}^{*}$ and $\gamma_{i j}^{*}$ have to do with the short-run dynamics of the model's convergence to equilibrium (Pesaran \& Pesaran, 2009). 
Accordingly the error-correction version of equation (1) is sketched out by the following equation:

$$
\begin{aligned}
\Delta \ln \mathrm{GDP}_{\mathrm{t}}=\lambda_{0} & +\sum_{\mathrm{j}=1}^{\mathrm{n}_{1}} \phi_{\mathrm{j}} \Delta \ln \mathrm{GDP}_{\mathrm{t}-\mathrm{j}}+\sum_{\mathrm{j}=1}^{\mathrm{n}_{2}} \beta_{\mathrm{j}} \Delta \ln \mathrm{GFCF}_{\mathrm{t}-\mathrm{j}}+\sum_{\mathrm{j}=1}^{\mathrm{n}_{3}} \gamma_{\mathrm{j}} \Delta \ln \mathrm{HCL}_{\mathrm{t}}+\sum_{\mathrm{j}=1}^{\mathrm{n}_{4}} \varpi_{\mathrm{j}} \Delta \mathrm{SERV}_{\mathrm{t}} \\
& +\delta_{1} \ln _{\mathrm{GDP}}+\delta_{\mathrm{t}-1}+\delta_{2} \ln \mathrm{GFCF}_{\mathrm{t}-1}+\delta_{3} \ln _{\mathrm{HCL}}^{\mathrm{t}-1}+\delta_{4} \mathrm{SERV}_{\mathrm{t}-1}+\xi_{\mathrm{t}}
\end{aligned}
$$

where $\mathrm{n}_{1}, \mathrm{n}_{2}, \mathrm{n}_{3}$, and $\mathrm{n}_{4}$ are the lags of the first-differenced variables.

In the ARDL model outlined by equation (10) first the null hypothesis of no cointegration (i.e, $\mathrm{H}_{0}: \delta_{1}=\delta_{2}=\delta_{3}=\delta_{4}=0$ ) is tested against the alternative (i.e, $H_{1}: \delta_{1} \neq 0, \delta_{2} \neq 0, \delta_{3} \neq 0, \delta_{4} \neq 0$ ) using the F-test which are automated in Softwares like Microfit 5 and more recent version of Eviews that deal with the ARDL equations of cointegration. The rule is that if the calculated F-statistic lies above the upper level of the band, the null hypothesis of no cointegration is rejected. If the estimated F-statistic falls below the lower level of the band, the null cannot be rejected. In applying the F-test, it is required to decide the number of lags to be imposed on the first-differenced variables because the results are a bit sensitive to the order of lags.

Following Seetanah (2008) and Tang (2003) this study uses a lag order of one to save the degree of freedom in the analysis. After ascertaining the presence of cointegration in the first step, the second step of the ARDL approach to cointegration involves the estimation of the short-run and long-run parameters.

Similarly the error-correction version of equation (2) is as outlined in equation (11):

$$
\begin{aligned}
\Delta \ln \operatorname{SERV}_{\mathrm{t}}=\mu_{0}+ & \sum_{\mathrm{i}=1}^{s_{1}} \pi_{\mathrm{i}} \Delta \ln \operatorname{SERV}_{\mathrm{t}-\mathrm{i}}+\sum_{\mathrm{i}=1}^{\mathrm{s}_{2}} \theta_{\mathrm{i}} \Delta \ln \mathrm{GDP}_{\mathrm{t}-\mathrm{i}}+\sum_{\mathrm{i}=1}^{s_{3}} \phi_{\mathrm{i}} \Delta \ln \mathrm{X}_{\mathrm{t}-\mathrm{i}}+\sum_{\mathrm{i}=1}^{s_{4}} \gamma_{\mathrm{i}} \Delta \ln \mathrm{M}_{\mathrm{t}-\mathrm{i}}+\sum_{\mathrm{i}=1}^{\mathrm{s}_{5}} \psi_{\mathrm{i}} \Delta \ln \mathrm{G}_{\mathrm{t}-\mathrm{i}} \\
& +\sum_{\mathrm{i}=1}^{s_{6}} \omega_{\mathrm{i}} \Delta \ln \mathrm{HCL}+\eta_{1} \ln \operatorname{SERV}_{\mathrm{t}-1}+\eta_{2} \ln \operatorname{GDP}_{\mathrm{t}-1}+\eta_{3} \ln \mathrm{X}_{\mathrm{t}-1}+\eta_{4} \ln \mathrm{M}_{\mathrm{t}-1}+\eta_{5} \ln \mathrm{G}_{\mathrm{t}-1} \\
& +\eta_{6} \ln \mathrm{HCL}_{\mathrm{t}-1}+\zeta_{\mathrm{t}}
\end{aligned}
$$

where $\mathrm{S}_{1}, \mathrm{~S}_{2}, \mathrm{~S}_{3}, \mathrm{~S}_{4}, \mathrm{~S}_{5}$ and $\mathrm{s}_{6}$ are the lags of the first-differenced variables.

In the ARDL model outlined in equation (11) first of all the null hypothesis of no cointegration (i.e, $H_{0}: \eta_{1}=\eta_{2}=\eta_{3}=\eta_{4}=\eta_{5}=\eta_{6}=0$ ) is tested against the alternative (i.e, $H_{1}: \eta_{1} \neq 0, \eta_{2} \neq 0, \eta_{3} \neq 0, \eta_{4} \neq 0, \eta_{5} \neq 0, \eta_{6} \neq 0$ ) using the F-test which are automated in Softwares like Microfit 5 and more recent version of Eviews that estimate the ARDL equations of cointegration. Thus following Pesaran, Shin and Smith (2001), 
cointegration can be expected if the long-run coefficients of all lagged level variables are jointly significant.

\section{RESULTS AND DISCUSSION}

\section{Unit Root Test}

The ARDL approach to cointegration is applicable irrespective of whether the regressors are I (0), I (1), or even integrated of the same order or mutually cointegrated. Therefore, before applying this method of cointegration, one has to test for the order of integration of all variables using the unit root tests to be sure that none of the variables are integrated of order 2 or beyond (Ouattara, 2004) because in the presence of I (2) variables the computed F-statistic provided by Pesaran, Shin and Smith (2001) are not valid and the given F-statistic cannot be interpreted. Therefore to test unit root in the time series of the study this study used the augmented Dickey-Fuller (ADF) unit root test (Dickey \& Fuller, 1979, 1981).The ADF equation for the unit root up to the pth autoregressive lag, $\mathrm{AR}_{(\mathrm{p})}$ is specified as:

$\Delta \mathrm{Y}_{\mathrm{t}}=\lambda+\phi \mathrm{t}+\delta \mathrm{Y}_{\mathrm{t}-1}+\beta_{1} \Delta \mathrm{Y}_{\mathrm{t}-1}+\beta_{2} \Delta \mathrm{Y}_{\mathrm{t}-2}+\ldots+\beta_{\mathrm{p}} \Delta \mathrm{Y}_{\mathrm{t}-\mathrm{p}}+\mathrm{u}_{\mathrm{t}},(\delta=\sigma-1)$

where $\mathrm{Y}$ is a time series under investigation; $\Delta$ is a difference operator; $\lambda$ is the intercept term $; \delta$ is the coefficient of one period lagged $Y ; \beta_{1}, \beta_{2}, \ldots, \beta_{\mathrm{p}}$ are the coefficients of the lagged changes of the variable $\mathrm{Y} ; \phi$ is the coefficient of the time trend $t$, and $u_{t}$ is the usual white noise error term.

The ADF equation for a unit autoregressive root given in equation (12) tests the null hypothesis that $\mathrm{H}_{0}: \delta=\sigma-1=0$ against the one-sided alternative $\mathrm{H}_{1}: \delta<0$ by applying OLS regression method. Under the null hypothesis, $Y_{t}$ has a unit root (i.e., $Y_{t}$ is nonstationary, it has a stochastic trend); under the alternative hypothesis $Y_{t}$ is stationary (does not contain stochastic trend). ADF unit root test was performed on all the variables $\ln$ GDP, $\ln S E R V, \ln G F C F, \operatorname{lnHCL}, \ln X, \ln \mathrm{M}$, and $\ln G$ used in the empirical analysis. The ADF test indicated that none of the variables were integrated of order two, I (2). This allowed the use of the ARDL approach to cointegration (NB: For the preservation of space the results of the ADF unit root test are not presented here).

\section{Cointegration Test}

The first part of this sub-section analyses the ARDL cointegration test result on the impact of service sector in the economic growth of Nepal. The result of the first step of the ARDL approach to cointegration of equation (1) is given in Table 2. 
Table 2 : ARDL Bounds Test; Dependent Variable is lnGDP

Sample(adjusted): 1976-2016 (Included observations: 41 after adjustment)

Maximum dependent lags: 1 (Automatic selection); Model selection method: Akaike info criterion (AIC)

Dynamic regressors (1 lag, automatic): lnGFCF lnHCL lnSERV ; Fixed regressors: C(Intercept)

Selected Model: ARDL $(1,0,0,0)$; Null Hypothesis: No long-run relationships exist

\begin{tabular}{ccc}
\hline Test Statistic & Value & Regressors(k) \\
\hline F-statistic & 18.14 & 3 \\
& Critical Value Bounds & \\
\hline Significance & $\mathrm{I}(0)$ Bound & $\mathrm{I}(1)$ Bound \\
\hline $10 \%$ & 2.37 & 3.20 \\
$5 \%$ & 2.79 & 3.67 \\
$1 \%$ & 3.65 & 4.66 \\
\hline
\end{tabular}

Source: Author's estimation

As the computed F-statistic of size 18.14 is greater than the upper bound based on conventionally used significance levels $(1 \%, 5 \%$, and $10 \%)$, the null hypothesis of no cointegration is rejected in favour of the alternative hypothesis that there exists long-run association in the time series. The estimates of the short-run and long-run coefficients of the model are given in Table 3.

Table 3 : ARDL Cointegrating and Long Run Form

Dependent Variable: $\operatorname{lnGDP}$

Selected Model: ARDL(1, 0, 0, 0)

Sample: 1975-2016 (Included observations: 41)

Cointegrating Form

\begin{tabular}{ccccc}
\hline Variable & Coefficient & Std. Error & t-Statistic & Prob. \\
\hline$\Delta \operatorname{lnGFCF}$ & 0.387 & 0.153 & 2.524 & 0.016 \\
$\Delta \operatorname{lnHCL}$ & 0.008 & 0.160 & 0.047 & 0.963 \\
$\Delta \operatorname{lnSERV}$ & 0.342 & 0.185 & 1.848 & 0.073 \\
ECT(-1) & -0.349 & 0.054 & -6.512 & 0.000
\end{tabular}

$\mathrm{ECM}=\operatorname{lnGDP}-(1.491 \mathrm{nGFCF}+0.121 \operatorname{lnHCL}+0.640 \operatorname{lnSERV}-14.095)$

\begin{tabular}{ccccc}
\hline Long Run Coefficients & \multicolumn{4}{l}{} \\
\hline Variable & Coefficient & Std. Error & t-Statistic & Prob. \\
\hline $\ln$ GFCF & 1.491 & 0.367 & 4.065 & 0.000 \\
$\operatorname{lnHCL}$ & 0.121 & 0.278 & 0.434 & 0.667 \\
$\operatorname{lnSERV}$ & 0.640 & 0.377 & 1.699 & 0.098 \\
C & -14.095 & 2.118 & -6.655 & 0.000 \\
\hline
\end{tabular}

Source: Author's estimation 
As regard to the short-run estimates, the one period-lagged error-correction term $\left(\mathrm{ECT}_{\mathrm{t}-1}\right)$ comes with expected negative sign and is statistically significant(at higher level of probality precision) in the GDP equation supporting the existence of longrun relationship. Negative and statistically significant coefficient of $\mathrm{ECT}_{\mathrm{t}-1}$ suggests that the time series are non-explosive and they adjust to the long-run equilibrium. As the coefficient of $\mathrm{ECT}_{\mathrm{t}-1}$ is -0.349 , it suggests that after disequilibrium the speed of adjustment to the equilibrium is about 34.9 percent per year; it takes around 3 years to converge to the long-run equilibrium.

The short-run coefficient of GFCF ( $\Delta \ln$ GFCF) is positive and statistically significant at 0.016 probability level. This suggests the positive role of capital formation in the growth of output. The size of coefficient of the variable ' $\Delta \ln \mathrm{GFCF}^{\prime}$ ' is 0.387 which would mean that other things remaining constant GDP would increase by about 0.39 percent if GFCF increases by 1 percentage point. The coefficient of the education-scaled labour force $(\triangle \ln \mathrm{HCL})$ is positive but statistically insignificant at the conventional level of significance. This would suggest that all else holding constant the labour force of the country polished by the level of school education is weak in increasing the level of real GDP. In a study of the cross-section growth Pritchett (2001) offered three explanations for the weak and negative effect of education on economic growth. First, the institutional/governance background could have been sufficiently unhealthy that the accumulation of educational capital lowered economic growth. Second, marginal returns to education could have fallen rapidly with the expansion of educated labour force amid its stagnant demand. Third, if quality of education is low it does not produce skillful human capital that would contribute to growth. Hanushek and Woessmann (2007) emphasise that quality of education matters even more for growth than quantity. The education variable (school level enrollment ratio) used in this study is a quantity measure of education.

The short-run coefficient of the service sector value added $(\Delta \ln$ SERV $)$ is positive as expected and statistically significant at the probability level of 0.073 (at $7.3 \%<$ $10 \%$ ). The positive coefficient of size 0.342 means that by holding constant other variables affecting GDP growth if services sector gross value added increases by 1 percentage point, overall real GDP would increase by about 0.34 percentage point. As pointed out in the conceptual framework part service sector contributes the growth and transformation of an economy (i) through direct impact (employment, exports, GDP), (ii) indirect impacts through input-output analysis (jobs and output in supplier industries), and (iii) second round effects (e.g., productivity effects and forward linkages). 
In the long-run estimates capital as a conventional type of input has positive and statistically significant effect on economic growth. The coefficient size of the variable 'lnGFCF' is slightly greater than 1 which would suggest that other things remaining constant if real gross fixed capital formation increases by 1 percentage point real GDP would rise by about 1.49 percentage point. The possible explanation for this may be that least developed countries like Nepal are capital-shortage economies and hence the increase in real capital stock through gross fixed capital formation would bring big increase in output; it may be that capital is used more efficiently to increase the productivity. The long-run estimate shows positive coefficient of the variable 'InSERV' which is statistically significant at the p-value of $0.098(9.8 \%<10 \%)$. The size of coefficient of 'InSERV' is 0.640 which would mean that all else being equal the increase in service sector value added by 1 percentage point would help increase the level of GDP of Nepal by about 0.64 percentage point. The possible explanation for the positive impact of the service sector on economic growth are spread in the introduction, literature review and theoretical framework of this study.

In the long-run estimate too, the positive coefficient of the education-scaled labour force $(\operatorname{lnHCL})$ is not statistically significant. The explanation for this result are the same as offered in the case of short-run estimates.

The validity of the estimated coefficients is confirmed by employing relevant diagnostic checks such as the Breusch-Godfrey (BG) Lagrange Multiplier (LM) tests for serial correlation, Breusch-Pagan-Godfrey test for heteroskedasticity, and Ramsey Regression Error Specification Test (RESET) for model misspecification. The diagnostic test results of the selected ARDL model is given in Table 4.

Table 4 : Diagnostic Test of Selected Model: ARDL (1, 0, 0, 0)

\begin{tabular}{lllll}
\hline Ramsey RESET Test & $\begin{array}{l}\text { Omitted Variables: Squares } \\
\text { of fitted values }\end{array}$ & Value & df & Probability \\
& t-statistic & 1.749 & 35 & 0.089 \\
& F-statistic & 3.059 & $(1,35)$ & 0.089 \\
\hline $\begin{array}{l}\text { Breusch-Godfrey Serial } \\
\begin{array}{l}\text { Correlation LM Test } \\
\text { (2 lags of residual) }\end{array}\end{array}$ F-statistic & Obs R-squared & 0.193 & Prob.F(2,34) & 0.826 \\
\hline $\begin{array}{l}\text { Heteroskedasticity Test: } \\
\text { Breusch-Pagan-Godfrey }\end{array}$ & F-statistic & 0.459 & Prob.Chi-Square(2) & 0.795 \\
& Obs R-squared & 1.117 & Prob.F(4,36) & 0.364 \\
& Scaled explained SS & 4.528 & Prob.Chi-Square(5) & 0.339 \\
\hline
\end{tabular}

Source: Author's calculation

The model fairly passes econometric pathology tests as the probability value ( $\mathrm{p}$-value) of the tests reported in Table 4 are greater than 5 percent level. Finally the CUSUM plot of Figure 3 confirms the stability of the estimated parameters. 


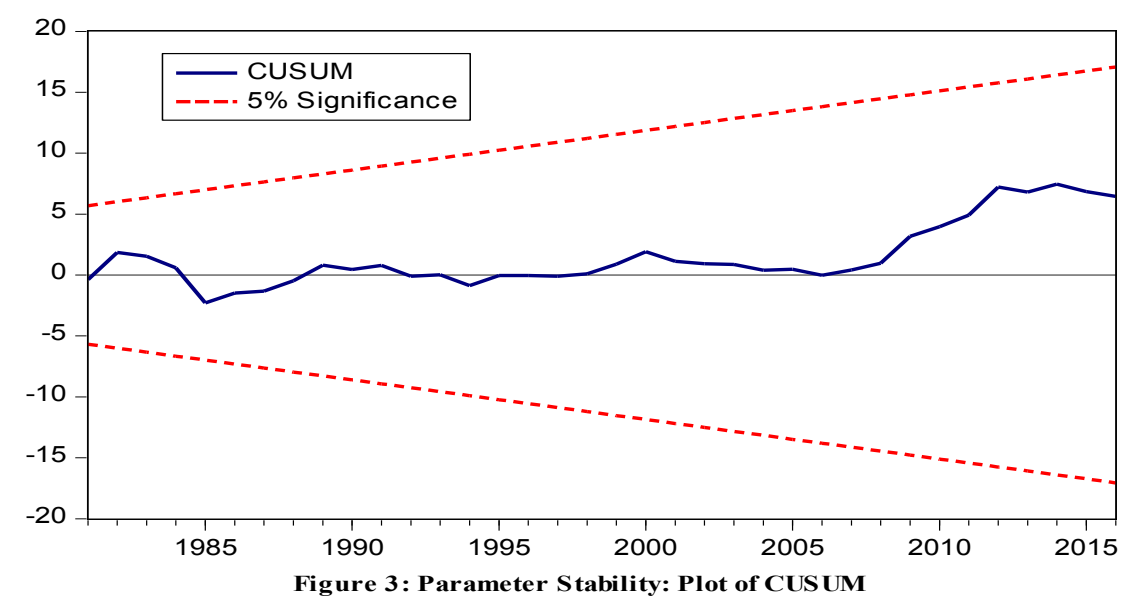

In the plot the CUSUM curve stays within the upper and lower bands at 5 percent level of significance. This suggests that long-run and short-run parameters of the selected ARDL model are stable and produce reliable estimation.

\section{Effect of GDP on Service Sector Growth}

This study has also tested whether real GDP has any significant impact on the services sector output. The result of the first step test of cointegration of specification (2) is given in Table 5.

Table 5: ARDL Bounds Test; Dependent Variable: lnSERV

Sample(adjusted): 1976-2016 (Included observations: 41 after adjustment)

Maximum dependent lags: 1 (Automatic selection)

Model selection method: Akaike info criterion (AIC)

Dynamic regressors (1 lag, automatic): $\operatorname{lnGDP} \ln X \ln M \ln G \ln H C L$

Fixed regressors:C(Intercept)

Selected Model: ARDL(1, 0, 0, 0,1,0)

Null Hypothesis: No long-run relationships exist

\begin{tabular}{lcl}
\hline Test Statistic & Value & Regressors $(\mathrm{k})$ \\
\hline F-statistic & 6.44 & 5 \\
& Critical Value Bounds & \\
\hline Significance & $\mathrm{I}(0)$ Bound & $\mathrm{I}(1)$ Bound \\
\hline $10 \%$ & 2.08 & 3.00 \\
$5 \%$ & 2.39 & 3.38 \\
$1 \%$ & 3.06 & 4.15 \\
\hline
\end{tabular}

Source: Author's estimation 
The result of the first step test indicates that the computed F-statistic of size 6.44 is fairly greater than the upper bound at 5 percent level of significance. So the null hypothesis of no cointegration in the model is rejected in favour of the alternate hypothesis of the existence of cointegration.

After deciding the presence of cointegration in the model, the second step of the ARDL bound testing approach involves the estimate of the short-run and long-run coefficients. The results are given in Table 6.

Table 6: ARDL Cointegrating and Long Run Form

Dependent Variable: $\operatorname{lnSERV}$

Selected Model: ARDL(1, 0, 0, 0, 1, 0)

Sample: 1975 -2016 ( Included observations:41)

\section{Cointegrating Form}

\begin{tabular}{|c|c|c|c|c|}
\hline Variable & Coefficient & Std. Error & t-Statistic & Prob. \\
\hline$\Delta \operatorname{lnGDP}$ & 0.338 & 0.069 & 4.876 & 0.000 \\
\hline$\Delta \ln X$ & 0.151 & 0.049 & 3.083 & 0.004 \\
\hline$\Delta \ln M$ & -0.141 & 0.109 & -1.289 & 0.206 \\
\hline$\Delta \ln G$ & 0.016 & 0.047 & 0.340 & 0.736 \\
\hline$\triangle \ln H C L$ & 0.226 & 0.100 & 2.253 & 0.031 \\
\hline $\mathrm{ECT}(-1)$ & -0.502 & 0.146 & -3.439 & 0.002 \\
\hline \multicolumn{5}{|c|}{$\mathrm{ECT}=\ln S E R V-(0.522 \ln \mathrm{GDP}+0.144 \ln X-0.325 \ln \mathrm{M}-0.121 \ln \mathrm{G}+0.322 \ln H C L+9.598)$} \\
\hline \multicolumn{5}{|c|}{ Long Run Coefficients } \\
\hline Variable & Coefficient & Std. Error & t-Statistic & Prob. \\
\hline $\operatorname{lnGDP}$ & 0.522 & 0.071 & 7.303 & 0.000 \\
\hline $\ln X$ & 0.144 & 0.050 & 2.865 & 0.007 \\
\hline $\ln M$ & -0.325 & 0.134 & -2.431 & 0.021 \\
\hline $\ln G$ & -0.121 & 0.067 & -1.799 & 0.081 \\
\hline $\operatorname{lnHCL}$ & 0.322 & 0.136 & 2.366 & 0.024 \\
\hline $\mathrm{C}$ & 9.598 & 1.127 & 8.513 & 0.000 \\
\hline
\end{tabular}

Source: Author's estimation 
In the estimates of the short-run, the one period-lagged error-correction term $\left(\mathrm{ECT}_{\mathrm{t}-1}\right)$ comes with expected negative sign and is statistically significant at the p-value of 0.002 supporting the existence of long-run relationship in the model. Negative and statistically significant coefficient of $\mathrm{ECT}_{\mathrm{t}-1}$ suggests that the time series are nonexplosive and they adjust to the long-run equilibrium. The size of the coefficient of $\mathrm{ECT}_{\mathrm{t}-1}$ which measures the speed of adjustments to the long-run equilibrium is -0.502; it suggests that convergence to the long-run equilibrium takes around 2 years (at an annual rate of about 50 percent).

In both the short-run and long-run estimates the coefficient of the real GDP variable is positive and statistically significant at higher level of significance. The coefficient of $\Delta \ln$ GDP is 0.338 which would mean that all else being equal the increase in real GDP by 1 percentage point would increase the service sector output $(\Delta \ln$ SERV) by about 0.34 percentage point. The long-run coefficient of the GDP variable (ln GDP) is 0.522 which would imply that other things remaining constant the increase in the level of real GDP by 1 percentage point would be followed by a 0.52 percentage point rise in the level of services sector output. One of the explanations offered for the shift of an economy to services sector is the Fisher-Clark Hypothesis (Fisher, 1935; Clark,1940) which is also known as the 'Hierarchy of Needs Hypothesis'. This hypothesis states that the proportion of the service sector increases as consumption structure changes from goods to services due to rise income. Another explanation is the famous 'Cost Disease Hypothesis' proposed by Baumol and his coauthors (Baumol, 1967; Baumol, Blackman, \& Wolff, 1985) who argue that an economy's shift towards services is caused by the transfer of resources from manufacturing to services due to the presence of productivity gap between the two sectors, rather than to the shift in final demand due to income growth as the traditional view argues.

As regard to the impact of export both the short-run and long-run estimates show positive and statistically significant impact of the export variable. In the short-run case the coefficient of $\Delta \ln X$ is 0.151 which would mean that all else being equal the increase in real export by 1 percentage point would bring rise in the service sector output $(\triangle \ln S E R V)$ by about 0.15 percentage point. The long-run coefficient of the real export variable $(\ln \mathrm{X})$ is 0.144 which would suggest that other factors remaining unchanged the increase in the level of real export by 1 percentage point would bring increase in the value of services sector by about 0.14 percentage point. The explanation for this positive impact of export trade on the services sector would be that the interconnection of the domestic economy with the rest of the world via export trade introduces greater degree of competition, keeps the economy connected with the modern technological developments and leads to higher levels of investment in the domestic economy that enhances the efficiency and productivity of the domestic service sector. 
But contrary to the prior expectation the import variable has negative impact on the service sector both in the short-run and long-run. Though the negative coefficient of import in the short-run estimate is statistically insignificant, it is statistically significant in the long-run estimate. The negative coefficient suggests that increase in import has not contributed in the enhancement of the service sector. It may be that import has increased country's dependency than enhancing efficiency and productivity of the service sector of Nepal.

As to the effect of education-glittered labour force, both the short-run and long-run estimates show that education enhances the growth of the services sector. In the shortrun estimate the statistically significant coefficient of size 0.226 of the variable $\Delta \ln \mathrm{HCL}$ would imply that other things holding constant a one percentage point increase in the labour force with school level education would increase service sector output by about 0.23 percentage point. In the long-run estimate the size of the statistically significant coefficient of the variable $\mathrm{lnHCL}$ is 0.322 which would mean that all else remaining constant the increase in the size of the labour force with some sort of school education by 1 percentage point would bring increase in the services sector by about 0.32 percentage point. The explanation for this result would be that services sector activities are naturally skill-oriented and hence the increase in the labour force with school level education is beneficial to this sector. Educated labour force is more essential to facilitate the diffusion and transmission of knowledge needed to understand and process new information and to implement new technologies developed by others (Nelson \& Phelps, 1966).

The impact of government's capital expenditure on the service sector growth is ambiguous. In the short-run estimate the coefficient of growth of government expenditure $(\Delta \ln G)$ is positive but statistically insignificant at the conventional level of significance but in the long-run estimate the coefficient of the variable level of government expenditure $(\ln G)$ is negative and statistically significant at the probability level of 0.081 . The negative coefficient would mean that all else remaining constant the increase in the level of government's capital expenditure by 1 percentage point would shrink the service sector by about 0.12 percentage point. One possible explanation for this negative effect would be the 'crowding out' effect of the public sector expenditure growth. It may also be that public sector's capital expenditure were not of the nature of stimulating service sector's activities.

For the reliability of the estimated results diagnostic tests like Ramsey's regression model fit, Breusch-Godfrey Serial Correlation LM test, and Breusch-Pagan-Godfrey's heteroskedasticity test were performed. Results of the tests of the selected ARDL $(1,0$, $0,0,1,0)$ model are given in Table 7 . 
Table 7: Diagnostic Test of Selected Model: ARDL (1, 0, 0, 0, 1, 0)

\begin{tabular}{llccc}
\hline Ramsey RESET Test & $\begin{array}{l}\text { Omitted Variables: } \\
\text { Squares of fitted values }\end{array}$ & Value & df & Probability \\
& t-statistic & 0.101 & 32 & 0.920 \\
& F-statistic & 0.010 & $(1,32)$ & 0.920 \\
\hline $\begin{array}{l}\text { Breusch-Godfrey Serial } \\
\begin{array}{l}\text { Correlation LM Test } \\
\text { (2 lags of residual entered) }\end{array}\end{array}$ & F-statistic & 0.014 & Prob.F(2,31) & 0.986 \\
\hline $\begin{array}{l}\text { Heteroskedasticity Test: } \\
\text { Breusch-Pagan-Godfrey }\end{array}$ & F-statistic & 0.037 & $\begin{array}{l}\text { Prob.Chi- } \\
\text { Square(2) }\end{array}$ & 0.982 \\
& Obs R-squared & 9.575 & $\begin{array}{l}\text { Prob.Chi- } \\
\text { Square(7) }\end{array}$ & 0.224 \\
& Scaled explained SS & 20.047 & $\begin{array}{l}\text { Prob.Chi- } \\
\text { Square(7) }\end{array}$ & 0.006 \\
\hline
\end{tabular}

Source: Author's calculation

The tests reported in Table 7 confirm the validity of the model. The model fairly passes the Breusch-Godfrey (BG) Lagrange Multiplier (LM) tests for serial correlation, BreuschPagan-Godfrey test for heteroskedasticity, and Ramsey Regression Error Specification Test (RESET) for model misspecification as indicated by the $\mathrm{p}$-values corresponding to each tests that are greater than 5 percent.Finally the CUSUM plot is accomplished as shown in Figure 4 to test for the stability of the estimated parameters.

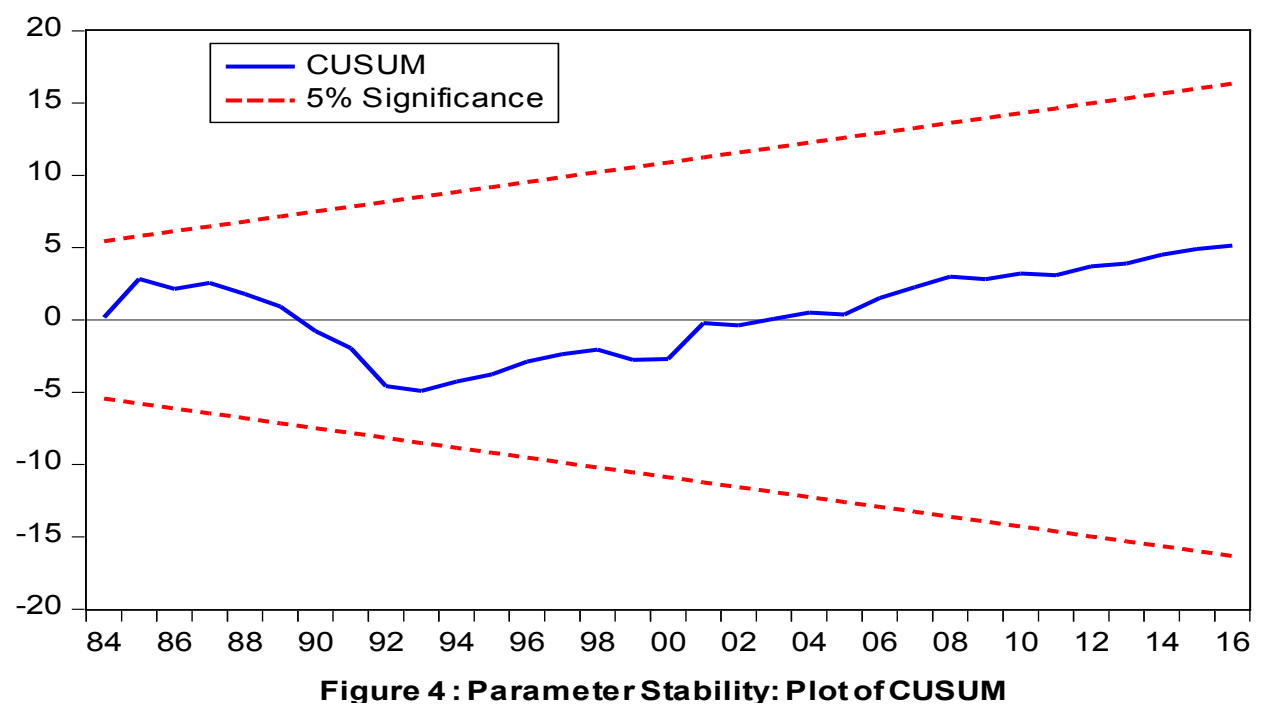


In the plot the CUSUM curve fairly remains within the upper and lower bands at 5 percent level of significance. This suggests that the long-run and short-run parameters of the selected ARDL model are stable and produce reliable estimation.

\section{POLICY IMPLICATIONS}

The findings of this study have some policy implications for the economy of Nepal which may also be applicable to economies similar to Nepal. First and foremost thing is related to the sustainability of the service-led growth in developing countries. Education, telecommunication, and connectivity (sound transportation infrastructure) are the secrets to flash and continue service-led growth. The infrastructure needs of services differ from manufacturing as services depend more on telecommunication and electricity and less on harbors and roads. Nepal needs to maintain and upgrade both the quantity and quality of her telecommunication infrastructure, and ensure uninterrupted supply of electricity in the country. In addition as the skill requirements in services are higher than in manufacturing and agriculture, investing in education for improving the quality of education to the global standard is of utmost importance. The empirical result of this study supports that education has statistically significant positive effect on service sector output.

Secondly, the empirical result of this study has shown that export trade has positive and statistically significant impact on the service sector of Nepal. Nepal is a member country of World Trade Organisation (WTO) and it has opened the services sector. Services are included in the multilateral trade design of WTO in the form of the General Agreement on Trade in Services (GATS), and international trade and investment in services are becoming increasingly important part of global business. GATS has four modes of supply in service trade (Knight, 2002): (i) Mode 1: Cross-border Supply, (ii) Mode 2: Consumption Abroad, (iii) Mode 3: Commercial Presence, and (iv) Mode 4: Presence of Natural Person. Progresses in information and communication technologies (ICT) have expanded the scope of services that can be traded cross-border. Therefore there is greater scope for the expansion of 'Nepal's service sector outside the national boarder. Analysts have pointed out the possibility that "the globalization of services provides alternative opportunities for developing countries to find niches, beyond manufacturing, where they can specialize, scale up, and achieve explosive growth, just like the industrialisers"(Ghani,2010,p.xvii).

Finally in the light of the rather shrinking manufacturing sector (as visualised from Figure 1 and 2 presented in the introduction section of this study), there is greater need for accelerating the manufacturing sector of the country. Services cannot substitute for industrial job creation. Every year large number of new work force enters to the labour market in Nepal but the service sector cannot alone provide job to the new labour 
force, and due to the lack of employment opportunity a substantial portion of the labour force goes foreign countries in search of job. The country cannot ignore the role of the manufacturing sector. If the manufacturing sector could be expanded it would create more employment opportunity to the growing labour force and help reduce imports of manufacturing products to some extent.

\section{CONCLUSION}

By employing the ARDL approach to cointegration on the time series data of the period 1975-2016, this study has analysed the role of expanding service sector in the economic growth of Nepal. In the sectoral change of the economy the service sector stands in the lead. Service sector is contributing to economic growth and growth is also causing service sector to expand via income effect. These empirical results are validated by a number of diagnostic tests like Ramsey RESET test, Breusch-Godfrey Serial Correlation LM test, and Breusch-Pagan-Godfrey's heteroskedasticity test, and CUSUM parameter stability test. Therefore based on the empirical results and taking into consideration the increasing speed of globalization ignited by revolution in information and communication technology (ICT) this study draws the conclusion that service sector of Nepal has greater potential to contribute in the economic growth of the country and manufacturing sector should also revive from the current lower level. One avenue for future research would be the comparative study of the productivity of the manufacturing and service sectors.

\section{References}

Altug, S., Filiztekin, A., \& Pamuk, S. (2008).Sources of long-term economic growth for Turkey, 1880-2005. European Review of Economic History, 12, 393-430.

Ansari, M.I. (1995).Explaining the service sector growth: An empirical study of India, Pakistan, and Sri Lanka. Journal of Asian Economics, 6, 233-246.

Bacon, R., \& Eltis, W. (1978).Britain's economic problem: Too few producers, $2^{\text {nd }}$ ed. London: Macmillan

Balchin, N., Hoekman, B., Martin, H., Mendez-Parra, M., Papadavid, P., Primack, D., \&te Velde, D.W. (2016). Trade in services and economic transformation, report. London: Supporting Economic Transformation (SET): Retrieved from http://cadmus.eui.eu/bitstream/handle/1814/44716/Trade-in-Services-andEconomic-Transformation_Final-Nov2016.pdf?sequence=1\&isAllowed=y

Baumol, W.J. (1967).Macroeconomics of unbalanced growth: The anatomy of urban crisis. American Economic Review, 57, 415-426. 
(1985).Productivity policy and the services sector. In R.P. Inman (Ed.), Managing the services economy: Prospects and problems (pp.301-317).Cambridge: Cambridge University Press.

. (2001).Paradox of the services: Exploding costs, persistent demand. In T. ten-Raa, \& Schettkat (Eds.), The growth of service industries: The paradox of exploding costs and persistent demand (pp.3-28).Elgar, Cheltenham (UK) and Northampton (Mass.).

Blackman, B., \& Wolff, N. (1985).Unbalanced growth revisited: Asymptotic stagnancy and new evidence. American Economic Review, 75, 806-817.

. (1989).Productivity and American leadership. Cambridge (Mass.): MIT Press.

Chari, V.V., Kehoe, P., \& McGrattan, E. (1997).The poverty of nations: A quantitative investigation. Federal Reserve Bank of Minneapolis (Working Paper 204). Retrieved from https://www.minneapolisfed.org/research/sr/sr204.pdf

Chenery, H.B. (1960).Patterns of industrial growth. The American Economic Review, 50, 624-654.

. (1988). Introduction to part 2.In H.B. Chenery \& T.N. Srinivasan (Eds.).Handbook of development economics, Vol.I (pp.197-202).Amsterdam, North Holland: Elsevier.

Robinson, S., \& Syrquin, M. (Eds.). (1986).Industrialization and growth: A comparative study. Oxford: Oxford University press.

\& Syrquin, M. (1975). Patterns of development, 1957-1970. London: Oxford University Press.

Clark, C. (1940).The conditions of economic progress. London: Macmillan and Co. Limited.

Dickey, D. A., \& Fuller, W. A. (1979). Distribution of the estimators for autoregressive time series with a unit root. Journal of the American Statistical Association, 74, 427-431.

. (1981). Likelihood ratio statistics for autoregressive time series with a unit root. Econometrica, 49, 1057-107

Easterly, W., Kremer, M., Pritchett, L., \& Summers, L.H. (1993).Good policy or good luck? Country growth performance and temporary shocks. Journal of Monetary Economics, 32, 459-483.

Eichengreen, B., \& Gupta, P. (2013).Two waves of service-sector growth. Oxford Economic Papers, 65, 96-123. doi:10.1093/oep/gpr059 
Engle, R.F., \& Granger, C.W. (1987).Cointegration and error correction: Representation, estimation, and testing. Econometrica, 55,251-267.

Fisher, A.G.B. (1935).The clash of progress and security. London: MacMillan and Co.Ltd.

Fixler, D.J., \& Siegel, D. (1999).Outsourcing and productivity in services. Structural Change and Economic Dynamics, 10,177-194.

Gani, A., \& Clemes, M.D. (2002).Services and Economic Growth in ASEAN economies. ASEAN Economic Bulletin, 19(2), 155-169.

Ghani, E. (Ed.). (2010).The service revolution in South Asia. New Delhi: Oxford University Press.

Greene, W. H. (2008).Econometric analysis, 6th ed. Upper Saddle River, NJ: PrenticeHall.

Greenhalgh, C., \& Gregory, M. (2001).Structural change and the emergence of the new service economy. Oxford Bulletin of Economics and Statistics, 63 (Special Issue), 629-646.

Government of Nepal, Ministry of Finance. (2011). Economic survey fiscal year 2010/11Vol. II. (Statistical tables). Kathmandu: Author.

. (2013).Economic survey fiscal year 2012/13. Kathmandu: Author. . (2017).Economic survey fiscal year 2016/17. Kathmandu: Author.

Hall, R.E., \& Jones, C.I. (1999).Why do some countries produce so much more output per worker than others? The Quarterly Journal of Economics, 114, 83-116.

Hanushek, E.A., \& Woessmann, L. (2007).Education quality and economic growth. Washington, DC. : The World Bank. Retrieved from http://siteresources. worldbank.org/EDUCATION/Resources/278200-1099079877269/5476641099079934475/Edu_Quality_Economic_Growth.pdf

Hoekman, B., \&te Velde, D.W. (2017). Introduction and overview. In B.Hoekman \& D.W.te Velde (Eds.), Trade in services and economic transformation: A new development policy priority (pp.1-4).London: Overseas Development Institute. Retrieved from http://cadmus.eui.eu/bitstream/handle/1814/45504/SETessays_2017_02.pdf?sequence $=1 \&$ isAllowed $=\mathrm{y}$

International Finance Corporation (IFC). (2013). IFC jobs study: Assessing private sector contributions to job creation and poverty reduction. Retrieved from http:// documents.worldbank.org/curated/en/157191468326714061/pdf/835080WP0I FC0J00Box382079B00PUBLIC0.pdf 
Jalil, A., \& Idrees, M. (2013).Modeling the impact of education on the economic growth: Evidence from aggregated and disaggregated time series data of Pakistan. Economic Modelling, 31,383-388.

Johansen, S. (1991).Estimation and hypothesis testing of cointegration vectors in Gaussian vector autoregressive models. Econometrica, 59, 1551-1580.

. (1995).Likelihood-based inference in cointegrated vector autoregressive models. Oxford: Oxford University Press.

Jouanjean, M.-A., Mendez-Parra, M., \&te Velde, D.W. (2015).Trade policy and economic transformation, brief. Retrieved from http://set.odi.org/wp-content/ uploads/2015/08/Trade-and-economic-transformation-13-July-2015.pdf

Khanna, A., Papadavi, P., Tyson, J., \& te Velde, D.W.(2016).The role of services in economic transformation-with an application to Kenya (SET Programme Report, February 2016).London: Supporting Economic Transformation (SET),p.10.Retrieved from http://set.odi.org/wp-content/uploads/2016/02/The-Role-of-Services-inEconomic-Transformation_Kenya.pdf

Knight, K. (2002).Trade talk: An analysis of the impact of trade liberalization and the general agreement on trade in services on higher education. Journal of Studies in International Education, 6(3), 209-229.

Kongsamut, P., Rebelo, S., \& Xie, D. (2001).Beyond balanced growth. The Review of Economic Studies, 68, 869-882.

Kuznets, S. (1957). Quantitative aspects of the economic growth of nations: II, industrial distribution of national product and labour force. Economic Development and Cultural Change, 5, 1-111.

Kuznets, S. (1966).Modern economic growth. New Haven: Yale University Press.

Lewis, W. A. (1954).Economic development with unlimited supplies of labour. The Manchester School, 22(2), 139-191.

Lucas, R.E., Jr. (1988).On the mechanics of economic development. Journal of Monetary Economics, 3, 3-42.

Mankiw, N.G., Romer, D., \& Weil, D.N. (1992).A contribution to the empirics of economic growth. Quarterly Journal of Economics, 107, 407-437.

Nelson, R. R., \& Phelps, E. (1966).Investment in humans, technology diffusion and economic growth. American Economic Review, 56, 69-75.

Ouattara, B. (2004). Modelling the long run determinants of private investment in Senegal (CREDIT Research Paper No 04/05). Centre for Research in Economic 
Development and International Trade, University of Nottingham. Retrieved from, http://www.nottingham.ac.uk/credit/documents/papers/04-05.pdf

Outlon, N. (2001).Must the growth rate decline? Baumol's unbalanced growth revisited. Oxford Economic Papers, 53, 605-627.

Pesaran, B., \& Pesaran, M.H. (2009).Time series econometrics using Microfit 5.0.Oxford: Oxford University Press.

Pesaran, M.H. \& Shin, Y. (1999).An autoregressive distributed lag modelling approach to cointegration analysis. In S. Strom (Ed.), Econometrics and economic theory in the 20 $0^{\text {th }}$ century: The Ragnar Frisch Centennial symposium, (pp.371-412). Cambridge: Cambridge University Press.

\& Smith, R. (2001).Bounds testing approaches to the analysis of level relationships. Journal of Applied Econometrics, 16, 289-326.

Phillips, P.C.B., \& Hansen, B.E. (1990).Statistical inference in instrumental variables regression with I (1) processes. Review of Economic Studies, 57, 99-125.

Pritchett, L. (2001). Where has all the education gone? The World Bank Economic Review, 15,367-391.

Rao, B.B., \& Vadlamannati, K.C. (2010).The level and growth effects of human capital in India. Applied Economics Letters, 18, 59-62. doi: 10.1080/13504850903427146

Riddle, D.I. (1986).Service-led growth. New York: Praeger Publications.

Riddle, D.I., \& Sours, M.H. (1984).Service industries as growth leaders on the Pacific Rim. Asia Pacific Journal of Management, 1(3), 190-199.

Rodrik, D. (2016).Premature deindustrialization. Journal of Economic Growth, 21(1), 1-33. http://dx.doi.org/10.3386/w20935. Retrieved from https://drodrik.scholar. harvard.edu/files/dani-rodrik/files/premature_deindustrialization.pdf

Romer, P.M. (1990).Human capital and growth: Theory and evidence. CarnegieRochester Conference Series on Public Policy, 32,251-286.

Rostow, W. (1960).The stages of economic growth: A non-communist manifesto. London: Cambridge University Press.

Senhadji, A. (2000).Sources of growth: An extensive growth accounting exercise. IMF Staff Papers, 47,129-157.

Seetanah, B. (2008).Financial development and economic growth: An ARDL approach for the case of the small island state of Mauritius. Applied Economic Letters, 15,809-813. 
Solow, R.M. (1956).A contribution to the theory of economic growth. The Quarterly Journal of Economics, 70, 65-94.

Stock, J., \& Watson, M.W. (1993). A simple estimator of cointegrating vectors in higher order integrated systems. Econometrica, 61,783-820.

Tang, T.C. (2003).Japanese aggregate import demand function: Reassessment from the bounds testing approach. Japan and the World Economy, 15,419-436.

Tregenna, F. (2015).Deindustrialisation, structural change and sustainable economic growth (UNIDO's Research, Statistics and Industrial Policy Branch Working Paper 2/2015).Vienna: United Nations Industrial Development Organisation (UNIDO).

World Bank. (2009).The service revolution in South Asia. Washington, DC: Poverty Reduction and Economic Management Unit, South Asia Region. 